\title{
Retrospective study of 151 patients with cutaneous leishmaniasis treated with meglumine antimoniate
}

\author{
Estudo retrospectivo de 151 pacientes com leishmaniose cutânea \\ tratados com antimoniato de meglumina
}

\author{
Armando de Oliveira Schubach ${ }^{1}$, Keyla B. Feldman Marzochi ${ }^{1}$, João Soares Moreira ${ }^{1}$, \\ Tânia Maria Pacheco Schubach ${ }^{1}$, Marcelo Lodi Araújo ${ }^{4}$, Antônio Carlos Francesconi do Vale ${ }^{2}$, \\ Sonia Regina Lambert Passos ${ }^{1,3}$ and Mauro Célio de Almeida Marzochi ${ }^{1}$
}

\begin{abstract}
We retrospectively analyzed a series of 151 cases of cutaneous leishmaniasis treated between 1967 and 1982. One-hundredand-thirty-nine (92\%) patients presented with active lesions and were treated with daily doses of meglumine antimoniate: 81 adults received a 5-ml vial IMand 58 children received 1 to 5ml. Forty-five (32.4\%) patients underwent continuous treatment with meglumine antimoniate for 25 to 116 days without rest intervals, and 94 (67.6\%) intermittent treatment with 2 to 5 series of meglumine antimoniate. Intermittent series could include schedules of daily IMapplications for 10 to 25 days each and intervals varying from 10 to 60 days. Antimony dose was calculated for 66 (47.5\%) patients and ranged from 3.9 to $28.7 \mathrm{Sb}^{5+} / \mathrm{kg} /$ day. Of these, 35 patients received $\geq 10 \mathrm{mg}$ and 31 patients $<10 \mathrm{mg} \mathrm{Sb}{ }^{5+} / \mathrm{kg} /$ day. Median time of healing was longer for lesions on the legs and feet - 67.5 days versus 48.7 days $(p<0.001)$ for other sites. However, there were no significant differences in the median time of healing between adults and children, intermittent and continuous regimens or high and low antimony doses. Fifty-one patients were reassessed 5 to 14 years after treatment and showed no evidence of disease. These results support further investigation ( clinical trials) on treatment using low doses of antimony. Key-words: Cutaneous Leishmaniasis. Leishmania (Viannia) braziliensis. Drug therapy. Meglumine antimoniate. Therapeutic schedules.

RESUMO

Descrição de uma série retrospectiva de 151 casos de leishmaniose cutânea atendidos entre 1967 e 1982. Destes, 139 (92\%) pacientes apresentavam lesões ativas e foram tratados com antimoniato de meglumina diariamente: 81 adultos receberam uma ampola de $5 \mathrm{ml}$ e 58 crianças receberam 1 a $5 \mathrm{ml}$. Quarenta e cinco (32,4\%) pacientes receberam tratamento antimonial contínuo durante 25 a 116 dias e $94(67,6 \%)$ receberam tratamento intermitente com 2 a 5 séries de antimoniato de meglumina, cada uma delas com duração de 10 a 25 dias e cujos intervalos de descanso entre as séries variaram de 10 a 60 dias. A dose de antimônio, calculada retrospectivamente em 66 (47,5\%) casos, variou entre 3,9 e 28,7mg Sh ${ }^{5+} / \mathrm{kg} / \mathrm{dia}$. Desses pacientes, 35 receberam $\geq 10 \mathrm{mg}$ e 31 receberam $<10 \mathrm{mg} \mathrm{Sh}{ }^{5+} / \mathrm{kg} /$ dia. Năo houve diferença significativa no tempo de cicatrização entre adultos e crianças, entre esquemas intermitentes eininterrupto, nem entre doses altas e baixas. Entretanto, 0 tempo de cicatrização nas pernas e pés (67,5 dias) foi superior ao encontrado em outras localizações ( 48,7 dias) $(p<0,001)$. Cinqüenta e um pacientes foram reavaliados entre cinco e 14 anos após o tratamento emantinham-se clinicamente curados. Essa série originou ensaios clínicos prospectivos utilizando doses baixas de antimônio no Rio de Janeiro.
\end{abstract}

Palavras-chaves: Leishmaniose Cutânea. Leishmania (Viannia) braziliensis. Terapêutica. Antimoniato de meglumina. Esquemas terapêuticos.

1. Centro de Referências em Leishmanioses do Instituto de Pesquisa Clínica Evandro Chagas da Fundação Oswaldo Cruz, Rio de Janeiro, RJ, Brasil. 2. Serviço de Especialidades Clínicas do Departamento de Doenças Infecciosas do Instituto de Pesquisa Clínica Evandro Chagas da Fundação Oswaldo Cruz, Rio de Janeiro, RJ, Brasil. 3. Departamento de Epidemiologia do Instituto de Pesquisa Clínica Evandro Chagas da Fundação Oswaldo Cruz, Rio de Janeiro, RJ, Brasil. 4. Serviço de Endoscopia Peroral do Hospital Geral de Bonsucesso, Rio de Janeiro, RJ, Brasil.

Address to: Dr. Armando Schubach. IPEC/FIOCRUZ. Av. Brasil 4365, 21040-900 Rio de Janeiro, RJ, Brasil.

Tel: 5521 3865-9536; fax: 5521 3865-9541

e-mail: armando@ipec.fiocruz.br

Recebido para publicação em 9/2/2004

Aceito em 5/3/2005 
In Rio de Janeiro, American tegumentary leishmaniasis (ATL) is caused by Leishmania (Viannia) braziliensis, whose transmission is dependent on the adaptation of the vector Lutzomyia intermedia to the peridomiciliary environment ${ }^{19}$. The disease affects the skin and mucosae. Cutaneous leishmaniasis (CL) presents as skin ulcers in body sites exposed to the sandflies' bite. These ulcers may regress without any treatment after a period of several months to years ${ }^{7}$. The patients may remain cured or reactivation of scars or development of mucosal lesions may occur $^{40}$. Mucosal leishmaniasis (ML) presents as chronic and destructive lesions of the oral, nasal, pharyngeal and/or laryngeal tissues. A higher risk of reactivation and development of ML is believed to be associated with incomplete or inadequate treatment ${ }^{16} 171841$.

Pentavalent antimonials have been used in the treatment of leishmaniasis for more than 60 years $^{11}$. Despite the broad spectrum of clinical and in vitro sensitivity to pentavalent antimonials exhibited by different species and strains of Leishmania around the world, some therapeutic guidelines have been suggested ${ }^{10}{ }^{1342}$. However, clinical assays continue to be performed to define the therapeutic regimen best suited to different regions of the globe ${ }^{33}$. The main differences between the therapeutic regimens available relate to the use of meglumine antimoniate or sodium stibogluconate, continuous or intermittent administration, total daily dose, duration of treatment, the criteria used for discontinuation or prolongation of treatment, and the Leishmania species and strains involved4.

Until the mid-eighties, the treatment protocol for adult ATL at Evandro Chagas Clinical Research Institute (IPEC) consisted of one daily 5-ml vial IM of meglumine antimoniate, irrespective of body weight ${ }^{37}$. We present here a retrospective series of CL cases treated with fixed doses of antimony independent of body weight, 51 of these were reassessed several years atter treatment. The objective of this paper was to present the retrospective series of cases that encouraged prospective cohort studies and clinical trials in Rio de Janeiro (Southeast Region of Brazil) using low doses of antimony ${ }^{29} 30$.

\section{MATERIAL AND METHODS}

The study was approved by the Ethics Committee of the Oswaldo Cruz Foundation (Fiocruz) and was conducted according to Resolution \#1/88 of the National Health Council ${ }^{24}$.

Retrospective study (record review). The records and charts of patients with ATL seen at IPEC from 1967 to 1982 were reviewed. To be included, the following information had to be available: a) an epidemiologic history consistent with ATLacquired in the State of Rio de Janeiro; b) presence of cutaneous lesions suggestive of CL; c) diagnosis based on a positive Montenegro skin test (MST) and/or demonstration of the parasite in culture, by direct examination or by histopathology; and d) treatment with meglumine antimoniate. Additionally, data about Leishmania species characterization based on monoclonal antibody, and isoenzyme analysis ${ }^{122}$ were obtained from the charts. Of the 333 records reviewed, only 151 (45.3\%) fulfilled the inclusion criteria.
Frequency distributions and medians with percentiles 25 and 75 are presented. We performed an analysis of treatment effectiveness. The results of treatment comprised presence or absence of a good therapeutic response, defined as a written record of complete scarring (healing) of the lesions after treatment. The time in days to achieve the results of treatment with meglumine antimoniate since the beginning of treatment was compared, according to the presence or absence of the following variables: age ( $>$ or $<18$ years), body site of the lesions (legs or foot versus other), dose of antimony administered ( $>$ or $<10 \mathrm{mg} / \mathrm{kg} /$ day), and continuous versus intermittent treatment. The Kolmogorov Smirnov test rejected all the null hypothesis concerning the normality of continuous variables distribution. Therefore, we chose the nonparametric MannWhitney test to compare median times of healing between groups.

Cross-sectional study (reassessment of the patients). Between September 1986 and January 1988, an active search for these patients was conducted. Fifty-one patients were located again and reassessed after signing the informed consent form to participate in the cross-sectional study. The patients were seen at IPEC for medical history and physical, dermatologic and ENT ( ears, nose and throat) examinations. The latter included anterior rhinoscopy, posterior rhinoscopy and laryngoscopy with Hopkins optics $0^{\circ}$ and 90 . Leishmanin was provided by the Institute of Biological Sciences, Federal University of Minas Gerais ${ }^{22}$ for MST. All tests and measurements with a ballpoint pen ${ }^{38}$ were performed by a single observer. An indirect immunofluorescence assay (IFA) was performed for the detection of anti-Leishmania antibodies ${ }^{5}$. Promastigotes of the Brazilian strain MHCM/BR/76/JOF, phenotypically similar to L major ${ }^{26}$, were used as antigen.

\section{RESULTS}

Retrospective study (record review). Of the 333 records reviewed, 151 fulfilled the inclusion criteria, with 137 (90.7\%) of them from the metropolitan region of Rio de Janeiro. Patients were 74 men and 77 women, median age 16 years with percentiles 25 and 75 of 8 to 30.8 years for age and 1 to 10 months ( median $=3$ months) for duration of disease.

The median number of lesions per patient was one. One-hundred-and-five (69.5\%) patients had single lesions, $22(14.5 \%)$ had two lesions and $24(16 \%)$ had three or more lesions. Upon treatment, 12 (8\%) patients had only scars suggestive of CL and 139 (92\%) had active lesions. The twelve patients ( 8 adults and 4 children aged up to 12 years) with cicatricial lesions at the beginning of treatment were excluded from the analysis of treatment effectiveness. These patients underwent prophylactic treatment to prevent the development of ML and received 50-125 doses of meglumine antimoniate. Leishmania was isolated from the scar of one of these patients 8 years after treatment with an intermittent schedul ${ }^{36}$.

Of these 139 patients, 114 (82\%) had ulcerated lesions, 8 (5.8\%) had papules or tuberous lesions, 4 (2.9\%) had infiltrative lesions, $1(0.7 \%)$ had verrucous lesions and for 12 (8.6\%) there was no information available. The location of the lesions was 
known in 132 patients, thirty-four (26\%) of which had active lesions in the feet or legs.

The MST was positive in $143(\mathrm{n}=147,97.2 \%)$ patients. IFA revealed serum titers between 1:40 and 1:320 in $27(n=40$, $67.5 \%)$ patients. The parasite was detected by direct examination, histopathology or culture in $38(\mathrm{n}=61,62.3 \%)$ patients. Nine out of 21 positive cultures were identified as L ( V.) braziliensis.

All patients received daily intramuscular meglumine antimoniate. Of the 139 patients with active lesions, 81 adults received a full 5 -ml vial daily and 58 children received a fraction of the vial, ranging from 1 to $5 \mathrm{ml}$ (median $2 \mathrm{ml}$ ), doses being determined empirically. In $66(n=139,47.5 \%)$ cases for which body weight was recorded, the median antimony dose $11 \mathrm{mg} / \mathrm{kg} /$ day ( $7.5 \mathrm{mg} / \mathrm{kg} /$ day to $15.3 \mathrm{mg} / \mathrm{kg} /$ day) could be calculated. Thirtyfive (53\%) of these 66 patients received $\geq 10 \mathrm{mg} \mathrm{Sb}{ }^{5+} / \mathrm{kg} /$ day and $31(47 \%)$ patients received <10mg.

Forty-five ( $\mathrm{n}=139,32.4 \%)$ patients underwent continuous treatment with meglumine antimoniate for 25 to 116 days, without rest intervals, and 94 (67.6\%) underwent intermittent treatment, consisting of 2 to 5 series of meglumine antimoniate with 10 to 25 days duration each, and intervals of 10 to 60 days between each series. However, 16 patients considered to have undergone a continuous regimen were in fact patients who did not return for additional therapy, because lesions healed after a single 25-day series.

Overall, the median time to healing after the beginning of treatment was 50 days ( 30 - 60 days). The median time (and percentiles 25 and 75) of healing was longer - 67.5 days (43.8 - 91.3 days) - for lesions in the legs and feet than for lesions at other sites - 48.7 days ( $30-60$ days) $(p<0.001)$.

Apparent differences in the median time of healing between adults ( 50 days) and children ( 40 days) ( $p=0.53$ ); intermittent ( 50 days) and continuous ( 40 days) regimen $(p=0.63)$; or high ( 50 days) and low (50 days) antimony doses ( $\mathrm{p}=0.88$ ) did not reach statistical significance ( Table 1).

Overall, the median number of injections per patient was 66 ( ranging from 25 to 125 and the median duration of treatment

\begin{tabular}{|c|c|c|c|}
\hline Variable & $\begin{array}{l}\text { Median time } \\
\text { to scarring (days) }\end{array}$ & $\begin{array}{l}\text { Percentiles } \\
25-75\end{array}$ & $\begin{array}{l}\mathrm{p} \text { value of Mann- } \\
\text { Whitney test* }\end{array}$ \\
\hline \multicolumn{4}{|l|}{ Age } \\
\hline adult $>18$ years $(\mathrm{n}=81)$ & 50.0 & $30.0-60.0$ & 0.53 \\
\hline children $\leq 17$ years $(n=58)$ & 40.0 & $30.0-60.0$ & \\
\hline \multicolumn{4}{|l|}{ Schedules } \\
\hline continuous ( $\mathrm{n}=45$ ) & 40.0 & $30.0-60.0$ & 0.63 \\
\hline intermittent ( $\mathrm{n}=94)$ & 50.0 & $30.0-60.0$ & \\
\hline \multicolumn{4}{|l|}{ Daily doses } \\
\hline$\geq 10 \mathrm{mg} \mathrm{Sb}{ }^{5+} / \mathrm{Kg} /$ day $(\mathrm{n}=35)$ & 50.0 & $30.0-70.0$ & 0.88 \\
\hline$<10 \mathrm{mg} \mathrm{Sb} b^{5+} / \mathrm{Kg} /$ day $(\mathrm{n}=31)$ & 50.0 & $30.0-60.0$ & \\
\hline \multicolumn{4}{|l|}{ Location of lesions } \\
\hline legs and feet ( $\mathrm{n}=34)$ & 67.5 & $43.8-91.3$ & 0.001 \\
\hline other $(n=98)$ & 48.7 & $30.0-60.0$ & \\
\hline
\end{tabular}

was 90.0 days with $50 \%$ of observations in the following interquartile interval ( 50 days - 110 days).

In the subgroup of patients undergoing continuous treatment $(n=45)$, there was a correlation between median duration of treatment - 40 days ( 25 - 58 days), median number of antimony injections received - $40(25-50)(r=0.99 ; p=0.000)$ and median time to healing - 40 days ( $30-60$ days) $(r=0.69$; $p=0.000$ ). In the subgroup of patients undergoing intermittent treatment, median duration of treatment was obviously longer 100 days ( 90 - 120) than the median number of antimonial daily injections - 75 ( 60 - 75). However, in this sub-group, both the median duration of treatment - 100 days ( $90-120$ days) and the median number of antimony injections - 75 (60 - 75) were greater than time until healing - 50 days ( 30 - 60 days) and they did not correlate with each other $(p=0.19 ; p=0.22$, respectively).

Cross-sectional study (reassessment of the patients). Fifty-one patients were reassessed at a median of seven years after treatment. Thirty-three of these patients had been treated with a known dose of antimony: 17 patients with $\geq 10 \mathrm{mg} \mathrm{Sh}{ }^{5+} / \mathrm{kg}$ body weight/day and 16 with $<10 \mathrm{mg}$. All patients were still living in their area of origin. There were 25 men and 26 women ranging from 10 to 63 years of age ( median $=23$ ). All patients remained asymptomatic and presented atrophic cutaneous scars and no mucosal lesions. The MST was positive in $50(n=50,100 \%)$ patients. The IFA was positive ( $\mathrm{IgG}=1: 40)$ in the serum of $5(\mathrm{n}=51,10 \%)$ patients.

\section{DISCUSSION}

We studied 151 patients with CL from Rio de Janeiro who had received one ampoule or less of meglumine antimoniate intramuscularly daily. The limitations of this study are related to bias inherent in uncontrolled real settings of treatment such as: difficulties in recovering data from charts of patients seen by different physicians; irregular data recording; different therapeutic schedules and variable criteria to evaluate response to therapy.

For the treatment of $\mathrm{CL}$, the World Health Organization ${ }^{42}$ has recommended the use of $10-20 \mathrm{mg} \mathrm{Sb^{5+ }} / \mathrm{kg}$ body weight/day, without interruption until cure, for at least three weeks ${ }^{31}$. In Brazil, the same daily dose for 20 days, with a maximum of 3 ampoules daily, is recommended. Re-treatment should be considered in cases in which complete scarring is not achieved three months after the end of the initial treatment ${ }^{10}$. It is interesting to note that both fixed doses of antimony used in patients described in the present study and restriction of the maximum daily dose in contemporary official Brazilian guidelines can lead to the use of doses lower than $10 \mathrm{mg} \mathrm{Sb}{ }^{5+} / \mathrm{kg}$ body weight/day.

Continuous or intermittent schedules with $20 \mathrm{mg} \mathrm{Sh}{ }^{5+} / \mathrm{kg}$ body weight/day are well tolerated, and intravenous administration has been preferred because pain and discomfort at the site of injection are frequent when large volumes are injected intramuscularly ${ }^{2341335}$. Other authors have reported renal tubular 
dysfunction, cardiac, hepatic, pancreatic and hematological alterations $^{18934}$. In Rio de Janeiro, continuous schedules with $5 \mathrm{mg} \mathrm{Sb}{ }^{5+} / \mathrm{kg}$ body weight/day has been safe and effective for treatment of ATL ${ }^{28} 290$. In this study, no significant difference in the time of healing was observed between the therapeutic schedules used and high and low doses. Unfortunately, adverse effects were not recorded on a regular basis in the charts reviewed.

It was reported that pentavalent antimony is rapidly excreted in urine ${ }^{6}$. Miekeley et a ${ }^{23}$ confirmed these results. However, in contrast to previous reports, this rapid excretion phase was followed by a slower one with a half-life $>50$ days. These authors found evidence of the in vivo conversion of meglumine antimoniate into the ionic species $\mathrm{Sb}^{5+}$ and $\mathrm{Sb}^{3+}$, leading to considerable concentrations of $\mathrm{Sb}^{3+}$ in body fluids as suggested previously ${ }^{43}$. This finding supports the hypothesis that the formation of $\mathrm{Sb}^{3+}$ may be responsible for both the observed longterm toxicity of the drug and its therapeutic action ${ }^{32}$.

In the present study, lesion healing had occurred within the period established by Brazilian therapeutic guidelines ${ }^{10}$ in $97.1 \%$ of the patients, despite the fact that healing time could be overestimated due to time elapsed from scarring to medical observation and recording on the chart. In the subgroup of patients who underwent continuous treatment, duration of treatment and time until healing were similar and scarring determined the interruption of antimonial administration. However some patients in this subgroup had shorter duration of treatment than time intervals until healing, suggesting that it may not been necessary to continue antimonial application until total healing of CL lesions occurs. In the sub-group of patients undergoing intermittent treatment, both the duration of treatment and the number of injections per patient were higher than time of healing, suggesting that, in these cases, one or more of the additional series were unnecessarily administered after lesion healing. Other studies have shown that cutaneous lesions which do not heal until the end of treatment could heal without the need for re-treatmentt. Lesions located on legs and feet take longer to heal, suggesting venous stasis could be a delaying factor, as previously reported ${ }^{18}$.

Persistence of the parasite in one patient without signs of active disease demonstrates that treatment did not always eliminate the parasite and that this might not be necessary to establish clinical healing.

The 51 patients reassessed 5 to 14 years after treatment remained asymptomatic and fulfilled the criteria used to define clinical cure of ATL ${ }^{42}$, i.e., healed skin lesions, absence of mucosal lesions and a positive MST. Five (10\%) patients presented positive IFA at low titers (1:40). Some investigators have suggested that a negative IFA should also be included in the criteria of cure ${ }^{39}$. However, the clinical value of persistent antibody levels for predicting ATL recurrence in endemic areas has been questioned ${ }^{1541}$. Other authors have obtained similar results with therapeutic schemes different from the ones currently recommended ${ }^{20}{ }^{21}$. Marsden ${ }^{18}$ suggested that a low dose of meglumine antimoniate for the treatment of CL might prevent involvement of the mucosae. Other investigators observed cutaneous relapse and evolution to ML in 3 to $9.1 \%$ of cases followed up for a period of 6 years after treatment ${ }^{14}{ }^{27} 41$. Walton et $\mathrm{a}^{40}$ has suggested the need for longer periods of observation.

The present study indicates that lower doses of antimony could be as effective as higher doses.

\section{ACKNOWLEDGMENTS}

We wish to thank Dr. Thyedimo de C. Peixoto (in memoriam) and Dr. Manoel Paes de Oliveira-Neto for the indication of the records of his past patients, the driver Manoel Soares (in memoriam); the social assistants Ana Luiza C. Oliveira, Ana Mariela G. Soares and Maria da Graça Soaresfor their performance in finding and recovering the patients; the medical students Aline Pacheco Schubach and Renata de Souza Coutinho for including the data in the databank; and Gabriel Grimaldi Jr and Hooman Momen for identification of the Leishmania isolates.

\section{REFERENCES}

1. Aronson NE, Wortmann GW, Johnson SC, Jackson JE, Gasser Jr RA, Magill AJ, Endy TP, Coyne PE, Grogl M, Benson PM, Beard JS, Tally JD, Gambel JM, Kreutzer RD, Oster CN. Safety and efficacy of intravenous sodium stibogluconate in the treatment of leishmaniasis: recent U.S. military experience. Clinical Infectious Diseases 27:1457-1464, 1998.

2. Azeredo-Coutinho RB, Mendonca SC. An intermittent schedule is better than continuous regimen of antimonial therapy for cutaneous leishmaniasis in the municipality of Rio de Janeiro, Brazil. Revista da Sociedade Brasileira de Medicina Tropical 3:477-481, 2002.

3. Ballou WR, McClain JB, Gordon DM, Shanks GD, Andujar J, Berman JD, Chulay JD. Safety and efficacy of high-dose sodium stibogluconate therapy of American cutaneous leishmaniasis. Lancet 2:13-16, 1987.

4. Berman JD. Chemotherapy for leishmaniasis: biochemical mechanisms, clinical efficacy, and future strategies. Reviews Infectious Diseases 10:560-586, 1988.

5. Camargo ME, Rebonato C. Cross-reactivity in fluorescence tests for Trypanosoma and Leishmania antibodies. A simple inhibition procedure to ensure specific results. The American Journal Tropical Medicine and Hygiene 18:500-505, 1969.

6. Chulay JD, Fleckenstein L, Smith DH. Pharmacokinetics of antimony during treatment of visceral leishmaniasis with sodium stibogluconate or meglumine antimoniate. Transactions Royal Society Tropical Medicine Hygiene 82:69-72, 1988.

7. Costa JM, Vale KC, Franca F, Saldanha AC, Silva J0, Lago EL, Marsden PD, Magalhães AV, Silva CM, Serra Neto A. [ Spontaneous healing of leishmaniasis caused by Leishmania Viannia braziliensis in cutaneous lesions]. Revista da Sociedade Brasileira de Medicina Tropical 23:205-208, 1990.

8. Deps PD, Viana MC, Falqueto A, Dietze R. [ Comparative assessment of the efficacy and toxicity of $\mathrm{N}$-methyl-glucamine and BP88 sodium stibogluconate in the treatment of localized cutaneous leishmaniasis]. Revista da Sociedade Brasileira de Medicina Tropical 33:535-543, 2000.

9. Franke ED, Wignall FS, Cruz ME, Rosales E, Tovar AA, Lucas CM, LlanosCuentas A, Berman JD. Efficacy and toxicity of sodium stibogluconate for mucosal leishmaniasis. Annals Internal Medicine 113:934-940, 1990.

10. Fundação Nacional de Saúde. Manual de Controle da Leishmaniose Tegumentar Americana, Ministério da Saúde, Brasília, 2000.

11. Goodwin LG. Pentostan (sodium stibogluconate); a 50-year personal reminiscence. Transactions Royal Society Tropical Medicine Hygiene 89:339-341, 1995. 
12. Grimaldi Jr G, McMahon-Pratt D. Monoclonal antibodies for the identification of New World Leishmania species. Memórias do Instituto Oswaldo Cruz 91:37-42, 1996.

13. Herwaldt BL, Berman JD. Recommendations for treating leishmaniasis with sodium stibogluconate ( Pentostam) and review of pertinent clinical studies. The American Journal Tropical Medicine and Hygiene 46:296-306, 1992.

14. Jones TC, Johnson Jr WD, Barretto AC, Lago E, Badaro R, Cerf B, Reed SG, Netto EM, Tada MS, Franca TF, Wiese K, Golightly L, Fikrig E, Costa JML, Cuba CC, Marsden PD. Epidemiology of American cutaneous leishmaniasis due to Leishmania braziliensis braziliensis. Journal Infectious Diseases 156:73-83, 1987.

15. Labrada M, Weigle K, Valderrama L, Saravia NG. [Evaluation of immunoglobin isotype specific to Leishmania in tegumentary American leishmaniasis]. Memórias do Instituto Oswaldo Cruz 84:409-416, 1989.

16. Llanos-Cuentas EA, Marsden PD, Cuba-Cuba CA, Barreto AC, Campos M. Possible risk factors in development of mucosal lesions in leishmaniasis. Lancet 2:295, 1984.

17. Llanos-Cuentas EA, Marsden PD, Lago EL, Barreto AC, Cuba CC, Johnson WD. Human mucocutaneous leishmaniasis in Três Braços, Bahia - Brazil. An area of Leishmania braziliensis braziliensis transmission. II: Cutaneous disease presentation and evolution. Revista da Sociedade Brasileira de Medicina Tropical 17:169-177, 1984.

18. Marsden PD. Mucosal leishmaniasis ("espundia" Escomel, 1911). Transactions Royal Society Tropical Medicine Hygiene 80:859-876, 1986.

19. Marzochi MAC, Marzochi KBF. Tegumentary and visceral leishmaniasis in Brazil. Emerging anthropozoonosis and possibilities for their control. Cadernos de Saúde Pública 10:359-375, 1994.

20. Marzochi MC, Coutinho SG, Sabroza PC, Souza WJS. [Indirect immunofluorescence reaction and intradermoreaction for American cutaneous leishmaniasis in residents of the Jacarepagua region (Rio de Janeiro) . Comparative study of results observed in 1974 and 1978]. Revista do Instituto de Medicina Tropical de São Paulo 22:149-155, 1980.

21. Mayrink W, Raso P, Melo MN, Michalick MS, Magalhães PA, Williams P, Costa CA, Dias M. American cutaneous leishmaniasis: disappearance of amastigotes from lesions during antimonial therapy. Revista do Instituto de Medicina Tropical de São Paulo 25:265-269, 1983.

22. Melo MN, Mayrink W, Costa CA, Magalhães PA, Dias M, Williams P, Araújo FG, Coelho MV, Batista SM. [ Standardization of the Montenegro antigen]. Revista do Instituto de Medicina Tropical de São Paulo 19:161-164, 1977.

23. MiekeleyN, Mortari SR, Schubach AO. Monitoring of total antimony and its species by ICP-MS and on-line ion chromatography in biological samples from patients treated for leishmaniasis. Analytical Bioanalytical Chemistry 372:495-502, 2002.

24. Ministério da Saúde, Centro Nacional de Epidemiologia. FUNASA. Resolução n⿳0 01/88 do Conselho Nacional de Saúde. Informe Epidemiológico do SUS ano IV:63-82, 1995

25. Momen H. Parasite characterization by zymodeme analysis. In: Morel CM (ed) Genes and Antigens of parasites. A laboratory manual edition, UNDP/ World Bank/FIOCRUZ, Rio de Janeiro, p. 11-120, 1984.

26. Momen H, Grimaldi Jr G, Pacheco RS, Jaffe CL, McMahon-Pratt D, Marzochi MC. Brazilian Leishmania stocks phenotypically similar to Leishmania major. The American Journal Tropical Medicine and Hygiene 34: 1076-1084, 1985

27. Netto EM, Cuba CC, Costa JL, Barreto AC, Rosa C, Marsden PD. Recurrence of South American tegumentary leishmaniasis. Lancet 1:501, 1986.

28. Oliveira-Neto MP, Mattos M, Pirmez C, Fernandes O, Goncalves-Costa SC, Souza CFS, Grimaldi Jr G. Mucosal leishmaniasis ( "espundia") responsive to low dose of N-methyl glucamine (Glucantime) in Rio de Janeiro, Brazil Revista do Instituto de Medicina Tropical de São Paulo 42:321-325, 2000.

29. Oliveira-Neto MP, Schubach A, Mattos M, Goncalves-Costa SC, Pirmez C. A low dose antimony treatment in 159 patients with American cutaneous leishmaniasis. Extensive follow-up studies ( up to 10 years). The American Journal Tropical Medicine and Hygiene 57:651-655, 1997.

30. Oliveira-Neto MP, Schubach A, Mattos M, Goncalves-Costa SC, Pirmez C. Treatment of American cutaneous leishmaniasis: a comparison between low dosage $(5 \mathrm{mg} / \mathrm{kg} /$ day) and high dosage $(20 \mathrm{mg} / \mathrm{kg} /$ day) antimony regimens. Pathologie Biologie 45:496-469, 1997

31. Rees PH, Keating MI, Kager PA, Hockmeyer WT. Renal clearance of pentavalent antimony ( sodium stibogluconate). Lancet 2:226-229, 1980.

32. Roberts WL, Berman JD, Rainey PM. In vitro antileishmanial properties of tri- and pentavalent antimonial preparations. Antimicrobial Agents Chemotherapy 39:1234-1239, 1995.

33. Romero GAS, Hueb M, D’Oliveira Jr A, Schubach A. Simpósio sobre Tratamento das Leishmanioses. Revista da Sociedade Brasileira de Medicina Tropical 34:58-68, 2001

34. Saenz RE, de Rodriguez CG, Johnson CM, Berman JD. Efficacy and toxicity of pentostam against Panamanian mucosal leishmaniasis. The American Journal Tropical Medicine and Hygiene 44:394-398, 1991.

35. Saldanha AC, Romero GA, Guerra C, Merchan-Hamann E, Macedo VO. [ Comparative study between sodium stibogluconate BP 88 and meglumine antimoniate in cutaneous leishmaniasis treatment. II. Biochemical and cardiac toxicity]. Revista da Sociedade Brasileira de Medicina Tropical 33:383-388, 2000

36. Schubach A, Marzochi MC, Cuzzi-Maya T, Oliveira AV, Araújo ML, Oliveira AL, Pacheco RS, Momen H, Conceição-Silva F, Coutinho SG, Marzochi KB. Cutaneous scars in American tegumentary leishmaniasis patients: a site of Leishmania (Viannia) braziliensis persistence and viability eleven years after antimonial therapy and clinical cure. The American Journal Tropical Medicine and Hygiene 58:824-827, 1998.

37. Schubach A, Miekeley N, Mortari SR, Moreira JS, Conceição-Silva F Salgueiro MM, Campos FV, Marzochi KBF, Marzochi MCA. Estudos sobre o metabolismo de antimônio e de suas espécies químicas no tratamento da Leishmaniose Tegumentar Americana com baixas doses de antimônio. Revista da Sociedade Brasileira de Medicina Tropical 35: 102-103, 2002

38. Sokal JE. Measurement of delayed skin test responses. New England Journal Medicine 293:501-502, 1975

39. Souza WJS, Coutinho SG, Marzochi MCA, Toledo LM, Gottlieb MV. [ Use of the indirect immunofluorescence test in the therapeutic follow-up of American cutaneous leishmaniasis]. Memórias do Instituto Oswaldo Cruz 77:247-253, 1982

40. Walton BC, Chinel LV, Eguia y Eguia O. Onset of espundia after many years of occult infection with Leishmania braziliensis. The American Journal Tropical Medicine and Hygiene 22:696-698, 1973.

41. Weigle KA, Valderrama L, Santrich C, Saravia NG. Recurrences of tegumentary leishmaniasis. Lancet 2:557-558, 1985.

42. World Health Organization. The Leishmaniases. WHO Technical Report Series. World Health Organization, Report № 701, 1984.

43. Yarbuth AL, Anez N, Pena YP, Burguera JL, Burguera A. Antimony determination in tissues and serum of hamsters infected with meglumine antimoniate. Annals Tropical Medicine Parasitology 88:37-41, 1994. 